\title{
Risk Factors Effecting Conversion from Laparoscopic Cholecystectomy to Open Surgery
}

\section{Kolesistektomi Esnasında Laparoskopik Cerrahiden Açık Cerrahiye Geçişi Etkileyen Risk Faktörleri}

(D) Türker Acehan1, (D) Emin Köse 2

${ }^{1}$ Recep Tayyip Erdoğan University Faculty of Medicine, Department of General Surgery, Rize, Turkey

2İstanbul University-Cerrahpaşa, Cerrahpaşa Faculty of Medicine, Department of General Surgery, İstanbul, Turkey

\section{Abstract}

Objective: Laparoscopic cholecystectomy has obvious advantages over open surgery, such as shorter hospital stay, lower morbidity, better cosmetic results and faster return to daily activities. However, in some cases, conversion to open technique may be inevitable for patient safety or for the management of complications having occurred. Although various risk factors have been identified in many studies, variables such as technical facilities, surgical technique and experience affect risk factors. Our study aims to identify these risk factors.

Method: In this study, 2,483 cholecystectomy cases performed in the general surgery clinic of our hospital between December 2013 and 2016 were retrospectively analyzed. 110 cholecystectomy cases initiated with open surgery and performed during another operation were excluded from the study, and 88 patients who were started laparoscopic surgery and converted to open surgery were selected for the study. Information on the demographic and clinical characteristics of the patients was obtained from hospital records. The data of an equal number of consecutively selected patients from the patients who were completed laparoscopically were obtained and compared, and whether these factors had a significant effect on conversion to open surgery was evaluated.

Results: The rate of conversion from laparoscopic cholecystectomy to open surgery was $3.7 \%$. The most common reason for conversion to open surgery was adhesion due to inflammation ( $n=65,73.9 \%)$. While male gender, advanced age, diabetes, median incision above the umbilicus, multiple millimetric calculus and increased wall thickness in ultrasonography had a significant effect on the conversion to open surgery $(p<0.001)$, there was no significant correlation with body mass index, pancreatitis, cholangitis, endoscopic retrograde cholangiopancreatography or abdominal surgery, anesthesia evaluation

\section{Öz}

Amaç: Laparoskopik kolesistektominin, ameliyat sonrası daha kısa hastanede kalış süresi, daha düşük morbidite, daha iyi kozmetik sonuçlar ve günlük aktivitelere daha hızlı dönebilme sağlaması gibi avantajları ile açık cerrahiye göre üstünlüğü aşikardır. Ancak bazı durumlarda açık tekniğe geçmek hasta güvenliği veya meydana gelmiş olan komplikasyonu yönetmek için kaçınılmaz olabilmektedir. Birçok çalışmada çeşitli risk faktörleri tanımlanmış olsa da teknik imkanlar, cerrahi teknik ve tecrübe gibi değişkenler risk faktörlerini etkilemektedir. Çalışmamız bu risk faktörlerinin tespit edilmesini amaçlamaktadır.

Yöntem: Çalışmada Aralık 2013-2016 tarihleri arasında hastanemiz genel cerrahi kliniğinde gerçekleştirilmiş 2,483 kolesistektomi olgusu retrospektif olarak incelenmiştir. Açık cerrahiyle başlanan ve başka bir operasyon sırasında uygulanan 110 kolesistektomi olgusu çalışma dışı bırakılarak, laparoskopik başlayıp açık cerrahiye geçilen 88 hasta araştırma için seçilmiştir. Hastaların demografik ve klinik özelliklerine ait bilgiler hastane kayıtlarından elde edilmiştir. Laparoskopik tamamlanan hastalardan ardışık seçilen eşit sayıda hastanın verileri elde edilerek karşılaştırılmış, bu faktörlerin açığa geçişe anlamlı etkisi olup olmadığı değerlendirilmiştir.

Bulgular: Laparoskopik kolesistektomiden açığa geçiş oranı \%3,7, en sık açığa geçiş nedeni ise enflamasyona bağlı adezyon $(n=65, \% 73,9)$ olarak bulunmuştur. Açığa geçiş üzerine erkek cinsiyet, ileri yaş, diyabet, göbek üstü medyan kesi, ultrasonografide multipl milimetrik kalkül ve duvar kalınlık artışı olmasının anlamlı etkisi olduğu tespit edilirken $(p<0,001)$, vücut kitle indeksi, pankreatit, kolanjit, endoskopik retrograd kolanjiopankreatikografi ya da batın operasyonu geçirmiş olma öyküsü, anestezi değerlendirme skoru ve laboratuvar değerleri ile anlamlı ilişki tespit edilmemiştir ( $p>0,05)$. Yatış ve operasyon süreleri açığa geçilen grupta anlamlı olarak daha uzun bulunmuştur $(p<0,001)$.

Address for Correspondence: Emin Köse, İstanbul University-Cerrahpaşa, Cerrahpaşa Faculty of Medicine, Department of General Surgery, İstanbul, Turkey

E-mail: dreminkose@yahoo.com ORCID: orcid.org/0000-0002-0888-2576 Received: 17.04.2021 Accepted: 26.07.2021

Cite this article as: Acehan T, Köse E. Risk Factors Effecting Conversion from Laparoscopic Cholecystectomy to Open Surgery. Bagcilar Med Bull 2021;6(3):280-286

${ }^{\odot}$ Copyright 2021 by the Health Sciences University Turkey, Bagcilar Training and Research Hospital Bagcilar Medical Bulletin published by Galenos Publishing House. 


\section{Abstract}

score and laboratory values ( $p>0.05)$. The durations of hospitalization and operation were found to be significantly longer in the open group $(p<0.001)$.

Conclusion: Male gender, advanced age, presence of diabetes, presence of supra-umbilical median incision, multiple millimetric calculus and increased wall thickness in ultrasonography are associated with increased rates of conversion from laparoscopic cholecystectomy to open surgery. If the coexistence of parameters that we find significant is detected in the preoperative period, it may be possible to take precautions such as involving the experienced surgical team in the operation, planning the operating room, and providing more detailed information to the patient.

Keywords: Laparoscopic cholecystectomy, open cholecystectomy, risk factor

\section{öz}

Sonuç: Erkek cinsiyet, ileri yaş, diyabet varlığı, göbek üstü medyan kesi varlığı, ultrasonografide multipl milimetrik kalkül ve duvar kalınlık artışı olması artmış açığa geçiş oranları ile birliktedir. Anlamlı bulduğumuz parametrelerin birlikteliğinin preoperatif dönemde tespit edilmesi halinde zor kolesistektomi olabileceği ve açığa geçiş riskinin artabileceği düşünülerek eğitim olgusu olarak seçilmeyerek tecrübeli cerrahi ekibin ameliyata dahil edilmesi, ameliyathanenin planlanması, hastaya daha ayrıntılı bilgi verilmesi gibi önlemleri almamız mümkün olabilmektedir.

Anahtar kelimeler: Açık kolesistektomi, laparoskopik kolesistektomi, risk faktörü

\section{Introduction}

Laparoscopic cholecystectomy, which was successfully completed for the first time by Mouret in 1987, became popular in a short time with the experience of surgeons, although it had high morbidity in the first years and became the gold standard in gallbladder pathologies (1). Today, laparoscopic cholecystectomy is one of the most widely used laparoscopic operations worldwide, and according to many literatures, more than $85 \%$ is completed laparoscopically $(1,2)$.

The shorter hospital stay, lower morbidity, better cosmetic results and faster return to daily activities are some of the reasons why laparoscopic cholecystectomy is advantageous compared to open surgery $(3,4)$. Although it is a safe surgical procedure, laparoscopic cholecystectomy can cause serious complications such as bile duct injuries. Therefore, deciding when to prefer open surgery to laparoscopic surgery and predicting which cases may be problematic are important factors in preventing these injuries.

Although there are publications that give the rate of conversion to open surgery as high as $35 \%$, the generally accepted rate is between $2 \%$ and $15 \%$ (1). Among the factors reported in the literature in relation to the high rate of conversion from laparoscopic to open surgery, advanced age, male gender, acute cholecystitis, obesity, unclear anatomy, bleeding, adhesions, bile duct injuries, and high leukocyte count can be listed $(1,5,6)$. The patients at risk for the conversion to open surgery can be determined by evaluating the demographic, biochemical and radiological findings of the patients before surgical treatment. Identifying these risk factors and knowing the risk in advance will provide a great advantage in the management of gallbladder pathologies through appropriate surgical timing. With the successful estimation of the possibility of conversion to the open surgery, the optimal timing for surgery will be determined, thus it will be possible to avoid disadvantages such as long hospital stay, more common wound complications, or decrease in patient comfort, and to reduce the cost, and it will be possible to provide costeffective treatment and prevent prolonged surgery time. In our study, it was aimed to determine these risk factors affecting the conversion to open surgery.

\section{Materials and Methods}

In our study, 2,483 cholecystectomy cases performed in the General Surgery Clinic of University of Health Sciences Turkey, Okmeydanı Training and Research Hospital between December 2013 and 2016 were retrospectively analyzed with the approval of the University of Health Sciences Turkey, Okmeydanı Training and Research Hospital Ethics Committee dated 08.11.2016 and numbered 538. Among these patients, 110 open cholecystectomy cases that were started with open surgery and applied during another operation were excluded from the study, and 88 patients who were started laparoscopically and converted to open surgery were included in the study.

Patients' age, gender, weight and height information, information about previous operations, additional diseases, symptoms and history of previous cholecystitis, parameters known to be related to cholecystopathy from routine preoperative laboratory examinations, ultrasonography (USG) findings and characteristics, if performed, preoperative endoscopic retograde cholanigopancreaticography (ERCP) history and findings, surgical findings, information about the duration and type of the surgery, the American Society of Anaesthesiologists' 
classification of Physical Health (ASA) scores (7) of the patients and the duration of hospitalization were obtained from the records of our hospital. The data of an equal number of patients, who were selected consecutively among the patients completed laparoscopically, were obtained and compared statistically, and it was evaluated whether there was a significant effect on conversion to open surgery.

\section{Statistical Analysis}

Mean, standard deviation, frequency and percentage values were used in the descriptive statistics of the data. The distribution of variables was measured with the Kolmogorov-Smirnov test. It was understood that the age variable showed a normal distribution, and all of the other continuous variables did not comply with the normal distribution. The relationship between the conversion to open surgery and age was evaluated by the independent sample t-test. The relationship between laboratory values, body mass index (BMI), duration of operation and hospitalization and conversion to open surgery was evaluated with the Mann-Whitney U test. The chi-square test was used in the analysis of qualitative independent data, and the Fischer's Exact test was used when chi-square test conditions were not met. SPSS 22.0 program was used in the analyses; $\mathrm{p}<0.05$ was accepted as the limit of significance.

\section{Results}

In our study, 2,483 cholecystectomy cases performed between December 2013 and 2016 were analyzed retrospectively, 110 of these patients underwent cholecystectomy during another operation or with direct open surgery, and these patients were excluded from the study. The remaining 2,373 cases were planned and started as laparoscopic cholecystectomy operation, but during the operation, 88 (3.7\%) of them were converted to open surgery for various reasons. When the reasons for converting to the open surgery during laparoscopic surgery were examined, the most common reason was adhesion due to inflammation with $73.9 \%(\mathrm{n}=65)$, followed by adhesion due to the prior operation, inability to see the gallbladder hilus, peroperative bleeding and bile duct injury (Table 1).

Of the 176 patients included in the study (88 open, 88 laparoscopic completed), $53.4 \%(\mathrm{n}=94)$ were male and $46.6 \%$ $(\mathrm{n}=82)$ were female. Male gender ratios were determined as $67 \%(n=59)$ and $39.8 \%(n=35)$ for the open surgery and laparoscopic completed surgery groups, respectively. Male

\begin{tabular}{|c|c|c|c|}
\hline & & Number & $\%$ \\
\hline \multirow{5}{*}{$\begin{array}{l}\text { Conversion } \\
\text { reasons }\end{array}$} & Adhesion due to inflammation & 65 & $73.9 \%$ \\
\hline & $\begin{array}{l}\text { Adhesion due to previous } \\
\text { operation }\end{array}$ & 15 & $17.0 \%$ \\
\hline & $\begin{array}{l}\text { The gall bladder hilus cannot } \\
\text { be seen }\end{array}$ & 5 & $5.7 \%$ \\
\hline & Bleeding & 2 & $2.3 \%$ \\
\hline & Bile duct injury & 1 & $1.1 \%$ \\
\hline
\end{tabular}

gender was found to be significantly higher in the open surgery group (chi-square test, $\mathrm{p}<0.001$ ) (Table 2 ).

The rate of patients with diabetes mellitus (DM), which is known to be significant in terms of the course of gallbladder diseases, was found to be $39.8 \%(n=35)$ and $17 \%(n=15)$, for the open surgery and laparoscopically completed surgery groups, respectively, and the presence of diabetes was found to be significantly higher in the open surgery group (chi-square test, $\mathrm{p}=0.001$ ). The rates of patients with a history of pancreatitis were $2.3 \%(\mathrm{n}=2)$ and $4.5 \%$ $(n=4)$ for the open surgery and laparoscopically completed surgery groups, respectively. The rates of patients with a history of cholangitis were determined as $9.1 \%(\mathrm{n}=8)$ and $2.3 \%(\mathrm{n}=2)$, respectively, and there was no statistically significant difference between the groups $(p>0.05)$. The rates of patients with a history of ERCP were determined as $13.6 \%(n=12)$ and $8 \%(n=7)$, respectively, and there was no statistically significant difference between the groups (p>0.05) (Table 2).

The rates of patients with multiple millimetric stones in the gallbladder and single stones larger than $1 \mathrm{~cm}$ on USG were $88.6 \%(n=78)$ and $11.4 \%(n=10)$ for the open surgery group. These rates were $63.6 \%(n=56)$ and $36.4(n=32)$ for the laparoscopic group. The presence of multiple millimetric stones was found to be significantly higher in the open surgery group (chi-square test, $\mathrm{p}<0.001$ ) (Table 2 ).

The rates of gallbladder wall thickness greater than $3 \mathrm{~mm}$ in USG were found to be $43.2 \%(n=38)$ and $8 \%(n=7)$, for the open surgery and laparoscopic groups, respectively. The presence of a gallbladder wall thickness higher than $3 \mathrm{~mm}$ was found to be significantly higher in the open surgery group (chi-square test, $\mathrm{p}<0.001$ ). The majority of the patients in both groups were found to be ASA 1 and 2, and there was no statistically significant difference between the groups in terms of ASA score ( $>>0.05$ ) (Table 2).

BMI values were found to be $29.8 \mathrm{~kg} / \mathrm{m}^{2}( \pm 5.8)$ in the open surgery group and $28.6 \mathrm{~kg} / \mathrm{m}^{2}( \pm 5.1)$ in the laparoscopic 
Table 2. Gender and medical characteristics of patients

\begin{tabular}{|c|c|c|c|c|c|c|c|c|}
\hline & & \multicolumn{2}{|c|}{$\begin{array}{l}\text { Conversion } \\
\text { group }\end{array}$} & \multicolumn{2}{|c|}{$\begin{array}{l}\text { Laparoscopic } \\
\text { group }\end{array}$} & \multicolumn{2}{|c|}{ Total } & \multirow[t]{2}{*}{$\mathbf{p}$} \\
\hline & & $\mathbf{n}$ & $\%$ & $\mathbf{n}$ & $\%$ & $\mathbf{n}$ & $\%$ & \\
\hline \multirow[t]{2}{*}{ Gender } & Male & 59 & 67 & 35 & 39.8 & 94 & 53.4 & $p<0.001$ \\
\hline & Female & 29 & 33 & 53 & 60.2 & 82 & 46.6 & \\
\hline \multirow[t]{2}{*}{ Diabetes mellitus } & Yes & 35 & 39.8 & 15 & 17 & 50 & 28.4 & $p=0.001$ \\
\hline & No & 53 & 60.2 & 73 & 83 & 126 & 71.6 & \\
\hline Pancreatitis history & No & 86 & 97.7 & 84 & 95.5 & 170 & 96.6 & \\
\hline \multirow[t]{2}{*}{ Cholangitis history } & Yes & 8 & 9.1 & 2 & 2.3 & 10 & 5.7 & $p>0.05$ \\
\hline & No & 80 & 90.9 & 86 & 97.7 & 166 & 94.3 & \\
\hline ERCP history & Yes & 12 & 13.6 & 7 & 8 & 19 & 10.8 & $p>0.05$ \\
\hline \multirow[t]{2}{*}{ Stone number/size } & $>1 \mathrm{~cm}$, single & 10 & 11.4 & 32 & 36.4 & 42 & 23.9 & $p<0.001$ \\
\hline & Multiple millimetric & 78 & 88.6 & 56 & 63.6 & 134 & 76.1 & \\
\hline \multirow[t]{2}{*}{ Gallbladder wall thickness } & $>3 \mathrm{~mm}$ & 38 & 43.2 & 7 & 8 & 45 & 26.1 & $p<0.001$ \\
\hline & $<3 \mathrm{~mm}$ & 50 & 56.8 & 81 & 92 & 131 & 73.9 & \\
\hline \multirow[t]{5}{*}{ ASA score } & ASA 1 & 34 & 38.6 & 41 & 46.6 & 75 & 42.6 & \multirow{4}{*}{$\mathrm{p}>0.05$} \\
\hline & ASA 2 & 39 & 44.3 & 41 & 46.6 & 80 & 45.5 & \\
\hline & ASA 3 & 13 & 14.8 & 6 & 6.8 & 19 & 10.8 & \\
\hline & ASA 4 & 2 & 2.3 & 0 & 0 & 2 & 1.1 & \\
\hline & Total & 88 & 100 & 88 & 100 & 176 & 100 & - \\
\hline
\end{tabular}

ERCP: Endoscopic retograde cholangiopancreaticography, ASA: American Society of Anaesthesiologists

\section{Table 3. Age, BMI, operating and hospitalization time information of the patients}

\begin{tabular}{|c|c|c|c|}
\hline & $\begin{array}{l}\text { Conversion } \\
\text { group }\end{array}$ & $\begin{array}{l}\text { Laparoscopic } \\
\text { group }\end{array}$ & $\mathbf{p}$ \\
\hline The average age ( \pm SD) & $57.9( \pm 12.9)$ & $50.2( \pm 14.9)$ & $p<0.001$ \\
\hline Operating time $(\mathrm{min})( \pm \mathrm{SD})$ & $116.1( \pm 21.5)$ & $56.9( \pm 21.3)$ & $p<0.001$ \\
\hline Hospitalization time (day) $( \pm$ SD) & $5.4( \pm 3.1)$ & $1.1( \pm 0.3)$ & $\mathrm{p}<0.001$ \\
\hline
\end{tabular}

group. There was no statistically significant difference between the groups $(p>0.05)$. When the operation times were measured and analyzed as the time from the first incision to skin closure, the average operation time was found to be $116.1( \pm 21.5)$ minutes in the open surgery group and $56.9( \pm 21.3)$ minutes in the laparoscopic group, and it was significantly longer in the open surgery group (MannWhitney $\mathrm{U}$ test, $\mathrm{p}<0.001)$. The mean hospitalization period was $5.4( \pm 3.1)$ days in the open surgery group and $1.1( \pm 0.3)$ days in the laparoscopic group, and it was significantly longer in the open surgery group (Mann-Whitney U test, $\mathrm{p}<0.001$ ) (Table 3).
There was no significant difference between the groups in the laboratory values of the patients in the preoperative period $(p>0.05)$.

\section{Discussion}

It is very difficult to predict which patient will be converted to open surgery during laparoscopic cholecystectomy. Although many risk analysis scales have been created in the literature to predict this situation, there is no assessment system in routine use yet $(1,2)$. Sutcliffe et al. (2) created a risk assessment system called conversion from laparoscopic to open cholecystectomy risk score. Various scores were given 
according to age, gender, cholecystectomy indication, ASA score, gallbladder wall thickness, and common bile duct diameter, and patients with a total of 6 or less were considered as low-risk patients for conversion to open surgery, while those who scored above 6 were considered high-risk patients (2). According to this score, it has been argued that low-risk patients may be training cases in hospitals where resident training is given, but high-risk patients should be operated by more experienced surgeons.

In the literature, the rate of conversion laparoscopic to open surgery is reported between 1.3 and $24 \%$, and inflammation in the Callot's triangle and related fibrosis have been reported as the most common reasons for conversion to open surgery $(1,8,9)$. Sutcliffe et al. (2) examined the records of 8,820 patients in the United Kingdom database and 11 different studies and reported the rate of conversion to open surgery as $3.4 \%$. Failure to provide safe vision and intraoperative complications such as intestinal perforation, hemorrhage, or bile duct injury have been reported as the most common conditions leading to conversion to open surgery (2). Beksac et al. (1) investigated 1,444 patients and found that the rate of conversion to open surgery was $7.7 \%$, and the most common reason for conversion to open surgery was the inability to reveal anatomical formations (72.3\%) due to inflammation and fibrosis. In our study, the rate of conversion during laparoscopic cholecystectomy was found to be $3.7 \%$, which is consistent with the literature.

In our study, when the reasons for conversion to open surgery were examined, the most common cause was adhesions due to inflammation with a rate of $73.9 \%$, followed by adhesions due to previous surgery, invisible gall bladder hilus, bleeding and bile duct injury, respectively. When the laparoscopically completed and conversion groups were compared in terms of gender, the number of male patients in the open surgery group was found to be significantly higher. Similarly, many authors reported male gender as a risk factor $(10,11)$. In the study of Sözen et al. (12), this situation was interpreted that men were admitted to hospital less when symptoms began, similarly, men decided to undergo surgery later, and their admission to the hospital was delayed due to the fact that the daily activities of men were more intense in our country (12). According to Ekici et al. (13), women may be more sensitive to the inflammatory changes of cholecystitis. In addition, anatomical differences and changes in dietary habits may cause these changes between genders.

Older age is a risk factor for conversion to open surgery in laparoscopic cholecystectomy (14). In our study, the mean age was 57.9 in the exposed group, while it was 50.2 in the laparoscopic group, and the average age of the patients in the open surgery group was found to be significantly higher. The importance of age as a risk factor may also be due to the increase in the number of cholecystitis attacks with age, concomitant diseases that increase with age, or a more severe course of cholecystitis in elderly patients. Although there are many studies reporting that the rates of complications and conversion to open surgery in obese patients are comparable to nonobese patients, obesity has been reported as a risk factor in many studies $(15,16)$. Beksac et al. (1) has found no significant relationship between obesity and conversion rates, and similarly, obesity was not found as a factor that significantly increased the risk in our study. In our study, when the groups were evaluated in terms of DM disease, which is known to be significant in terms of the course of gallbladder diseases, the rate of patients with DM was found to be significantly higher in the group that converted to open surgery. Studies show that the incidence of gangrenous cholecystitis increases in patients with diabetes and this situation increases the risk of conversion to open surgery. In addition, due to the rapid progression of cholecystitis in diabetic patients, early cholecystectomy is recommended instead of delayed cholecystectomy following conservative treatment (17).

Choledocholithiasis is the most common biliary disease observed in patients who underwent cholecystectomy due to cholelithiasis, and its frequency varies between $10 \%$ and $20 \%$ (18). After small stones fall from the cystic duct into the main bile duct, it can be complicated by conditions such as gallstone disease, pancreatitis or cholangitis. This may increase the possibility of adhesion formation due to inflammation in the operation area (18). However, in our study, no significant relationship was found between the history of pancreatitis and cholangitis and conversion to open surgery. In our study, it was determined that patients with multiple millimetric stones in the bladder have a significantly increased risk of conversion to open surgery compared to patients with stones larger than $1 \mathrm{~cm}$ and single stones. This situation can be explained by the fact that small stones cause cholecystitis by obstructing the cystic duct.

In the literature, there are studies reporting that having an abdominal operation poses a risk for conversion to open surgery $(19,20)$. In our study, history of having an abdominal operation did not significantly affect the conversion to open surgery. 
In the literature, there are studies reporting cholecystitis findings such as increased bladder wall thickness and presence of pericholecystic fluid in USG as risk factors $(1,20)$. Chand et al. (3) investigated the effectiveness of preoperative USG in 50 patients. Various parameters in predicting the conversion to open surgery was investigated and it was reported that only the increased gallbladder wall thickness, increased common bile duct diameter, contraction of the gallbladder and the presence of impacted stones had a significant effect on the prediction of conversion to open surgery (3). In our study, gall bladder wall thickness higher than $3 \mathrm{~mm}$, which is a sign of acute or previous cholecystitis, emerged as a parameter that significantly increased the risk in conversion to open surgery.

Bourgouin et al. (4) investigated the relationship between blood neutrophil and platelet count, prothrombin time, fibrinogen, C-reactive protein, gamma glutamyl transferase (GGT) and alkaline phosphatase (ALP) values and conversion rates. While the relationship between neutrophil count, fibrinogen level and ALP value was found to be statistically significant, no relationship was found between the other parameters and the conversion to open surgery (4). Beksac et al. (1) found that ALP value above $80 \mathrm{IU} / \mathrm{L}$ was a risk factor in their study, but no significant relationship was found between leukocyte, ALT, AST, GGT, total bilirubin values and the conversion rates. In the study, it was evaluated that the patients' episodes of cholecystitis might be responsible for the elevation of ALP (1). In our study, although the laboratory values of ALT, AST, ALP, GGT, amylase, total bilirubin, direct bilirubin, leukocyte and platelet counts and neutrophil and lymphocyte percentages were examined, no significant relationship was found between these values and conversion rates.

With the advancement of technology, laparoscopy devices have also improved and provided a better view. Similarly, although the development of surgical instruments has contributed to the advancement of surgical technique and skills, conversion to open surgery during laparoscopic cholecystectomy may still have to be carried out even in the best centers. It is very difficult to predict which patient will be exposed.

\section{Conclusion}

According to our study, the factors affecting the conversion to open surgery are the observation of male gender, advanced age, presence of diabetes, presence of supra-umbilical incision, multiple millimetric calculus and cholecystitis findings such as increased wall thickness in USG. If the concomitance of these parameters is determined in the preoperative period, it may be possible to take precautions such as involving the experienced surgical team in the operation, planning the operating room, and providing more detailed information to the patient, considering that it may be difficult cholecystectomy and the risk of conversion to open surgery may increase. In clinics such as our hospital, a scoring method can be developed to predict patients at high risk of exposure, and more experienced surgeons and more advanced technological devices can be used for these patients. In addition, the first approach to be preferred should be laparoscopic cholecystectomy, even in the presence of factors that increase the risk of opening, and high-risk patients should at least be given the chance to benefit from the advantages of laparoscopy. Since the design of our study is retrospective, patient consent could not be obtained.

\section{Ethics}

Ethics Committee Approval: In our study, 2,483 cholecystectomy cases performed in the General Surgery Clinic of University of Health Sciences Turkey, Okmeydanı Training and Research Hospital between December 2013 and 2016 were retrospectively analyzed with the approval of the University of Health Sciences Turkey, Okmeydanı Training and Research Hospital Ethics Committee dated 08.11.2016 and numbered 538.

Informed Consent: Since the design of our study is retrospective, patient consent could not be obtained.

Peer-review: Externally peer-reviewed.

\section{Authorship Contributions}

Concept: T.A., E.K., Design: T.A., E.K., Data Collectionor Processing: T.A., E.K., Analysis or Interpretation: T.A., E.K., Writing: T.A., E.K.

Conflict of Interest: No conflict of interest was declared by the authors.

Financial Disclosure: The author declared that this study has received no financial support.

\section{References}

1. Beksac K, Turhan N, Karaagaoglu E, Abbasoglu O. Risk factors for conversion of laparoscopic cholecystectomy to open surgery: a new predictive statistical model. J Laparoendosc Adv Surg Tech A 2016;26(9):693-696.

2. Sutcliffe RP, Hollyman M, Hodson J, Bonney G, Vohra RS, Griffiths EA; CholeS study group, West Midlands Research Collaborative. Preoperative risk factors for conversion from laparoscopic to open 
cholecystectomy: A validated risk score derived from a prospective U.K. database of 8820 patients HPB (Oxford) 2016;18(11):922-928.

3. Chand P, Singh R, Singh B, Singla RL, Yadav M. Preoperative ultrasonography as a predictor of difficult laparoscopic cholecystectomy that requires conversion to open procedure. Niger J Surg 2015;21(2):102-105.

4. Bourgouin S, Mancini J, Monchal T, Calvary R, Bordes J, Balandraud P. How to predict difficult laparoscopic cholecystectomy? Proposal for a simple preoperatıve scoring system. Am J Surg 2016;212(5):873-881.

5. Gupta N, Ranjan G, Arora MP, Goswami B, Chaudhary P, Kapur A, et al. Validation of a scoring system to predict difficult laparoscopic cholecystectomy. Int J Surg 2013;11(9):1002-1006.

6. Atmaram DC, Lakshman K. Predictive factors for conversion of laparoscopic cholecystectomy. Indian J Surg 2011;73(6):423-426.

7. ASA Physical Status Classification System, American Society of Anesthesiologists, Approved by the ASA House of Delegates on October 15, 2014, and last amended on December 13, 2020. Available from: https://www.asahq.org/standards-andguidelines/asa-physical-status-classification-system

8. Radunovic M, Lazovic R, Popovic N, Magdelinic M, Bulajic M, Radunovic L, et al. Complications of laparoscopic cholecystectomy: our experience from a retrospective analysis. Open Access Maced J Med Sci 2016;4(4):641-646.

9. Le VH, Smith DE, Johnson BL. Conversion of laparoscopic to open cholecystectomy in the current era of laparoscopic surgery. Am Surg 2012;78(12):1392-1395.

10. Kaafarani HM, Smith TS, Neumayer L, Berger DH, Depalma RG, Itani KM. Trends, outcomes, and predictors of open and conversion to open cholecystectomy in Veterans Health Administration hospitals. Am J Surg 2010;200(1):32-40.

11. Genc V, Sulaimanov M, Cipe G, Basceken SI, Erverdi N, Gurel M, et al. What necessitates the conversion to open cholecystectomy? A retrospective analysis of 5164 consecutive laparoscopic operations. Clinics (Sao Paulo) 2011;66(3):417-420.
12. Sözen S, Emir S, Bali I. Laparoskopik kolesistektomiden açı ameliyata geçme nedenleri. Int J Basic Clin Med 2014;2(1):8-13.

13. Ekici U, Tatlı F, Kanlıöz M. Preoperative and postoperative risk factors in laparoscopic cholecystectomy converted to open surgery. Adv Clin Exp Med 2019;28(7):857-860.

14. WarchałowskiŁ, Łuszczki E, BartosiewiczA, Dereń K, Warchałowska $\mathrm{M}$, Oleksy $\mathrm{t}$, et al. The analysis of risk factors in the conversion from laparoscopic to open cholecystectomy. Int J Environ Res Public Health 2020;17(20):7571.

15. Tang B, Cuschieri A. Conversions During Laparoscopic Cholecystectomy: Risk Factors And Effects On Patient Outcome. J Gastrointest Surg 2006;10(7):1081-1091.

16. Malla B, Shakya Y, Rajbhandari N. Laparoscopic cholecystectomy: conversion rate and associated factors for Conversion. Kathmandu Univ Med J 2019;17(67):241-244.

17. Terho PM, Leppäniemi AK, Mentula PJ. Laparoscopic cholecystectomy for acute calculous cholecystitis: a retrospective study assessing risk factors for conversion and complications. World J Emerg Surg 2016;11:54.

18. Kwon YH, Cho CM, Jung MK, Kim SG, Yoon YK. Risk factors of open converted cholecystectomy for cholelithiasis after endoscopic removal of choledocholithiasis. Dig Dis Sci 2015;60(2):550-556.

19. Aksoy F, Demiral G, Ekinci Ö. Can the timing of laparoscopic cholecystectomy after biliary pancreatitis change the conversion rate to open surgery? Asian J Surg 2018;41(4):307-312.

20. Haji A, Khan A, Haq A, Ribeiro B. Elective laparoscopic cholecystectomy for surgical trainees: predictive factors of operative time. Surgeon 2009;7(4):207-210. 